\title{
Teaching the electric power and industry terminology during Coronavirus
}

\author{
Tolganay Kurmanbayeva - Damina Shaibakova - Meirimkul Tuleup - \\ Marzhan Nurmakhanova - Karlygash Kubdasheva
}

DOI: 10.18355/XL.2021.14.01.13

\begin{abstract}
This paper is devoted to the study of general issues of teaching English terminology in the electric power industry during the Coronavirus. The outbreak of the pandemic posed a serious challenge to education systems around the world. For the first time ever, traditional face-to-face training turned out to be impossible. Governments' decision to make distance education compulsory on all levels in the context of the coronavirus pandemic was unprecedented but needed. The development of the electric power industry affects the state of various industries and the daily life of people around the world. The search for alternative forms of education during the time of the crisis, therefore, became urgent. The aim of our research paper was to create a substantiated, experimentally proven methodology for teaching students terminological vocabulary of the professional language of the electric power industry during Coronavirus. In addition, we identified strategies for mastering professional terminological vocabulary pertaining to reading specialized texts as well as to oral communication in professionally significant communication situations focused on the electric power industry. To achieve this goal, the following tasks needed to be completed: (1) to study linguistic, psychological, psycholinguistic, methodological literature on the problems of teaching terminological vocabulary; (2) to determine the features of the functioning of the lexical skills of operating with professional terms; (3) to determine the lexical features of the terminological vocabulary of the sublanguage "the electric power industry"; (4) to develop based on this typology a technology for teaching students the skills of using terminological vocabulary in the process of oral and written communication; (5) to check the effectiveness of the proposed methodology in the process of experiential learning.
\end{abstract}

Key words: semantic characteristics, teaching, vocabulary, professional language, electric power industry, Coronavirus

\section{Introduction}

The world is living in a new digital age, and a lot has been said about it. Various development scenarios were developed: somewhere quickly, somewhere slowly. But the crisis forced them to find solutions rapidly. And in general, the education system managed to withstand the first wave. In order to improve the quality of education, state-sponsored online seminars are held daily on various aspects of organizing training using distance educational technologies. All universities and colleges have a HelpDesk system that provides technical support to students and teachers. The education system must learn from the current situation and take the necessary measures. (Zatkova, Ambrozy, 2019; Kobylarek, 2010).

To solve these problems with teaching students during Coronavirus, it was necessary to prepare materials, programs, record video lessons, develop new rules for teaching, assessment and instructions, conduct training courses for teachers, and deploy special Internet platforms for distance learning and find viable ways to explain these tools and procedures to parents and the general public.

Taking into account the existing problems and opportunities, after studying international experience, recommendations of UNESCO and the World Bank, we

XLinguae, Volume 14 Issue 1, January 2021, ISSN 1337-8384, eISSN 2453-711X 
decided to use several distance learning technologies at once: training via the Internet; training through television and radio; regular training in remote villages, as well as sending educational materials through the post office in settlements where there are no schools. In modern conditions, the study of the features of the formation of foreign language communicative competence is due to the need to train highly qualified specialists who can work in new conditions, taking into account the requirements of the labor market and the development of international professional ties. The system of higher education provides training for specialists in various fields. Nevertheless, there is a shortage of qualified specialists not only possessing professional knowledge but also characterized by personal qualities necessary for becoming a specialist able to compete in the global market. These include: the presence of a common culture; the ability to adapt to changing production conditions; the ability to take responsibility for the decisions made, to realize the creative potential; and knowledge of a foreign language in professional activities (Kunanbayeva, 2006).

In the era of internationalization and globalization of the education system, the factors of tolerance and sociability are becoming increasingly important, and the ranges of intercultural cooperation are significantly expanding. With the active development of economic and political ties and increasing competition, it becomes necessary to systematically improve the professional qualifications and mobility of employees. Changes are taking place in all areas of our life, and the education system is no exception. Currently, in the Khazaki education system, the issue of integrating some academic subjects into certain areas of knowledge is relevant, which contributes to the achievement of high results in the study of these disciplines (Pustovalova, 2008). The promoted strategic prospects for the development and modernization of Kazakhstan, defined in the "Development Strategy of the Republic of Kazakhstan until 2050" (Nazarbayev, 2019) and "The third modernization of Kazakhstan: global competitiveness" (Nazarbayev, 2018), determine the target orientation of the "State Program for the Development of Education of the Republic of Kazakhstan for 2011 2020" (Nazarbayev, 2010). In connection with the globalization of education and the expansion of our country's cultural, economic, and political borders, and the entry into the international educational space, there is a need to study foreign languages. Most important in the current global environment is undoubtedly English. Thus, it has become crucial to train specialists ready for foreign language professional communication in this language, with a particular focus on using relevant professional vocabulary.

It should be noted that in modern conditions, the function of a foreign language as a means of forming a professional orientation is of paramount importance. Among other things, this means that interest in the future profession and the desire to gain knowledge through the largest possible number of communication channels, one of which in this case becomes knowledge of a foreign language, makes it possible to get acquainted with the achievements in the professional field (Chaklikova, 2011). This aim is realized through an adequate organization of the entire educational process, designing a viable content of the educational material itself while focusing its orientation, as well as through implementing proper methods of introducing this material to the students. In addition, engaging forms of interaction between the teacher and the students in the educational process play an essential role. At the same time, a two-way connection is established between the student's desire to acquire special knowledge and the success of mastering a foreign language (Zimnyaya, 2001). The experience of working with students of the Almaty University of Energy and Communications named after G. Daukeev showed that formal or mechanical unification of the humanities and special sciences without deep penetration of their interpenetration in the educational process of a higher educational institution does not bring the desired result. Teaching proficiency in a modern professionally-oriented foreign language is aimed not only at the formation of foreign language 
communicative competence of students but also to improve the level of professional training. Despite the variety of approaches and the wide array of their theoretical and practical significance, the problem of the formation of foreign language communicative competence of students of non-linguistic universities in the process of professionally-oriented education as an integral part of their professional competence is relevant. Currently, in professionally oriented teaching of a foreign language in a non-linguistic university, a new methodology is needed for the selection of training content, which ensures the development of interdisciplinary connections. Interdisciplinary connections in higher professional education express the unification of the processes occurring at the present stage in science and in the life of society. These connections play a significant role in raising the level of quality of human and scientific and theoretical training of students, an essential feature of which is the mastery by students of the generalized nature of the cognitive activity. The development of interdisciplinary connections allows us to consider the content of education as a whole, connected with all the goals facing a non-linguistic higher education institution. In this regard, it is required to develop a structurally meaningful model of the formation of a foreign language communicative competence in the course of studying a professionally-oriented foreign language vocabulary of the professional language of the electric power industry.

The conducted research demanded an appeal to the works of modern foreign teachers, in which the problems of approaches to the formation of foreign language communicative competence are being developed, among other D. Wilkins (2004), Harding, (2007), Hartman (2009); numerous studies in the CIS countries (Beam, 2007), (Biboletova, 2005); as well as research by Kazakh scientists, such as Atabaeva (2004), Zhetpisbaeva (2006), Kunanbaeva (2006), and others.

\section{Research methods}

To implement the tasks, we used the following methods: theoretical analysis of domestic and foreign psychological, pedagogical, lingua didactic, and methodological literature on the problem under study; generalization of pedagogical experience on the range of issues under investigation, as well as a systematization of personal teaching experience at a university; detailed analysis of educational standards, model programs, curricula, textbooks and teaching aids in the context of the research; ascertaining and forming pedagogical experiment; observation, testing, questioning of students of a non-linguistic university; quantitative and qualitative analysis of the experimental results. (Gadusova, Haskova, Predanocyova, 2019)

The experimental research base was Almaty University of Energy and Communications, named after G. Daukeev, Kazakhstan, Almaty. The experiment was also conducted online. Naturally, distance learning does not mean simply translating traditional content, methods, and programs into teaching over the Internet. This is an overly simplistic and ineffective understanding of the process. To work in the new mode, new teaching methods, new pedagogical technologies, diagnostic and monitoring procedures must be developed, programs, lesson structure must be changed, and a transition to more flexible and individualized standards must be made.

The survey results showed the willingness of students of the experimental group to work with the professional terminological vocabulary of the professional language of the electric power industry. The process of learning had to take place online. The pandemic situation, however, did not affect their desire and confidence that this activity will improve their knowledge of the professional language and contribute to mastering the means of communication, helping them later in life in their professional activities (Table 1).

XLinguae, Volume 14 Issue 1, January 2021, ISSN 1337-8384, eISSN 2453-711X 


\section{Indicators in\%}

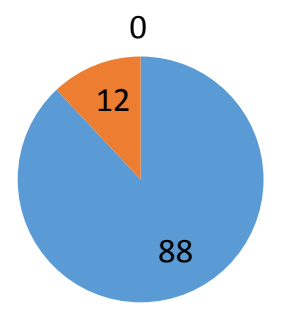

ready

not ready

do not know

\section{Table 1}

Each of the stages of the implementation of professional language (PL) activities has its own purpose in the formation of competence. The first stage contributes to the formation of goal-setting skills, develops the ability to plan their activities, systematizes PL knowledge, and enhances skills to search for information in foreign sources. After the completion of the PL training course, a final section of experimental training was conducted. Comparing the results after the training with the results measured at the initial stage of experiential learning revealed quantitative and qualitative changes in the level of proficiency in professional skills among students, which helped us evaluate the effectiveness of the proposed methodology. For the final chart, we used similar input tests for the possession of the PL and for the possession of communication tools appropriate to the context of the situation. Indicators of the level of formation of the terminological vocabulary of the professional language of the electric power industry competence in the course of experimental learning are shown in Table 2.

Indicators of the level of formation of terminological vocabulary usage skills of the professional language of the electric power industry of students (in \%)

\begin{tabular}{|c|c|c|c|c|c|c|c|c|}
\hline & \multirow[t]{3}{*}{ Indicators } & \multirow{3}{*}{$\begin{array}{l}\text { Stages } \\
\text { of the } \\
\text { experim } \\
\text { ent }\end{array}$} & \multicolumn{4}{|c|}{ Levels } & & \\
\hline & & & \multicolumn{2}{|l|}{ Low } & \multicolumn{2}{|c|}{ Average } & \multicolumn{2}{|l|}{ High } \\
\hline & & & EG & KG & EG & KG & EG & KG \\
\hline \multirow[t]{2}{*}{1} & \multirow{2}{*}{$\begin{array}{l}\text { Completeness of } \\
\text { use of terms }\end{array}$} & Start & 34,9 & 44,8 & 48,6 & 41,5 & 16,3 & 13,1 \\
\hline & & the end & 5,5 & 46,2 & 64,1 & 42,1 & 31,3 & 14,3 \\
\hline \multirow[t]{2}{*}{2} & \multirow{2}{*}{$\begin{array}{lr}\text { Accuracy } & \text { of } \\
\text { achieving } & \text { the } \\
\text { communicative goal }\end{array}$} & Start & 21,8 & 35,8 & 62,7 & 54,7 & 15,7 & 8,6 \\
\hline & & the end & $\begin{array}{l}\text { the } \\
\text { end }\end{array}$ & $\begin{array}{l}\text { the } \\
\text { end }\end{array}$ & $\begin{array}{l}\text { the } \\
\text { end }\end{array}$ & $\begin{array}{l}\text { the } \\
\text { end }\end{array}$ & $\begin{array}{l}\text { the } \\
\text { end }\end{array}$ & $\begin{array}{l}\text { the } \\
\text { end }\end{array}$ \\
\hline \multirow[t]{2}{*}{3.} & \multirow{2}{*}{$\begin{array}{l}\text { The amount of } \\
\text { recoverable } \\
\text { information in the } \\
\text { process with the } \\
\text { materials of the PL }\end{array}$} & Start & 45,5 & 17,7 & 68,4 & 67,2 & 18,1 & 43,4 \\
\hline & & the end & 5,5 & 89,6 & 63,5 & 68,6 & 27,5 & 14,3 \\
\hline \multirow[t]{2}{*}{4.} & \multirow{2}{*}{$\begin{array}{l}\text { Student activity in } \\
\text { the work on PL }\end{array}$} & Start & 12,3 & 13,6 & 64,3 & 65,7 & 24,7 & 22,8 \\
\hline & & the end & - & 15,3 & 48,8 & 68,5 & 53,9 & 18,8 \\
\hline
\end{tabular}

Table 2 
From the results presented in table 2 it can be concluded that the level of the terminological vocabulary of the professional language of the electric power industry of students of experimental groups has increased significantly. For example, if at the beginning of the experimental work a low level in the achievements in the EG showed $21.8 \%$, and in the CG $27.9 \%$, then at the end of the experiment, there were practically no students with a low level in the EG (only 4.1\%) while in the CG there was practically no change: the beginning $-27.2 \%$, the end $-27.9 \%$.

Given the above results, PL courses were carried out systematically. As a result of these courses, students learned how to work more independently. In addition, they acquired the necessary knowledge, skills, and abilities when working on project tasks. At the same time, they carried out different types of assignments (depending on the stage of work) and received all the necessary information for organizing such work in their activities. During the process, it was essential to provide the necessary equipment: servers, communication channels, proctoring systems, and communication equipment. Thus, the relevant equipment requirements may have to be included already in the licensing of educational activities. To effectively build a learning trajectory, summary information is needed, the so-called "digital footprint," which should include data on the content, learning tools, results obtained, and the degree of student engagement. Besides, work in new conditions has shown the need to change the education management system. The experience of introducing remote technologies has clearly demonstrated the importance of closer coordination and building clear connections in management.

\section{Discussion}

The transition to distance learning is enormous. It is certainly important to provide the necessary infrastructure, but a much greater challenge is providing adequate teachers' support, as well as high quality and relevant digital educational materials. In addition, a focus on developing students' digital skills for effective use of technology for learning and introducing them to the available support data systems and information management proved to be equally indispensable. Many education systems intending to move to online learning due to school closures, first consider using instructional videos instead of lectures in class. Education systems that planned to simply write long lectures by teachers so that students can listen to them online often find out that only the most highly motivated and diligent learners can process such content and even then with varying degrees of success. Video tutorials over the Internet (such as in Khan Academy), particularly for self-study assistance and in cases where the education system can purchase such content or create it, are more efficient. Best practices suggest that the shorter the content, the easier it is for learners to use it and cognitively process the material. Should an education setting experience some technical difficulties, such as self-posting video content, they can require an external provider's services, for example, to host content and accompanying technical support. In principle, in academic subjects that predominantly provide lectures and/or independent mastering of the material, it is easier to make a quick transition to online training. Subjects with digitized learning content, especially if it clearly conforms to schools' official curriculum, have advantages in the transition to online learning in the short term versus non-digital subjects content.

Along with the general principles of vocabulary selection, we have used special principles for the selection of terminological vocabulary of the professional language of the electric power industry for teaching during Coronavirus. Let us list these principles: a) the principle of the term's ability to express the concept in congruence with the "terminological vocabulary of the professional language of the electric power industry" is based on the essence of the lexical meaning; b) the principle of compliance with the goals and objectives of training in a university, in accordance

XLinguae, Volume 14 Issue 1, January 2021, ISSN 1337-8384, eISSN 2453-711X 
with which a student of the university should know basic terminology of their broad and narrow specialty; read and understand with a dictionary the available written sources within the narrow specialty; participate in the discussion of topics related to the specialty; c) a quantitative principle that helped to identify the frequency of terms; d) on the basis of the principle of word-formation value, terms were included in the minimum dictionary, which made it possible to form new terms with the help of word-formation elements; e) the principle of field formation made it possible to select terms with a more general meaning, i.e., extensional ones, and also terms with a narrow meaning, i.e., intensional terms. Extensional terms are basic. They form the core of the functional terminological field, while intensional terms are located at the periphery of the field. The conceptual meaning of intensional terms can be derived from the conceptual meaning of the basic term; f) the principle of semanticcontrastive value. In accordance with this principle, contrastively practical terms were included in the minimum dictionary, i.e., terms whose equivalent meanings are difficult to find; g) the principle of combinatory value was used to select terms that allow the formation of the largest number of phrases typical for the language; $h$ ) according to the principle of thematic, the terms were divided into topics. This principle of selection of terminological vocabulary is primarily focused on the goals of education in a university setting.

For educational purposes, the minimum dictionary is organized according to functional and terminological fields. Within the experiment, the following terminological associations were distinguished: a) a contrastive set; b) taxonomy; c) partonemia; d) cyclicity; e) word-formation series; f) paradigms (gender, number, etc.); g) functional fields and rows.

The principles of selection of terminological vocabulary of professional orientation indicated above, and the proposed variant of its organization for educational purposes in the form of a manual make the process of teaching students the terminological vocabulary a more successful, efficient, and strictly controlled process.

In the process of working on the terminological vocabulary of professional orientation, it is necessary to use the following strategies: a) cognitive, b) informational, c) compensatory. Each type of strategy corresponds to specific techniques aimed at improving the process of mastering this type of vocabulary. Methods of working on the terminological vocabulary of the professional language of the electric power industry include: highlighting certain features of the given terms and their identification; comparison and classification of terms, their systematization; search and extraction of information; generalization, assessment, and interpretation of information; the use of guesswork, equivalent substitutions, paraphrases, combining, etc. These have proved to be especially effective when used based on a single-purpose as well as multi-purpose contexts. The use of single and multi-purpose contexts makes it possible to use a variety of lexical contextual exercises to consolidate the semantics of terms in this sublanguage.

The results of the semantization of terms in the terminological vocabulary of the professional language of the electric power industry are consolidated using a system of lexically directed exercises. This system of exercises is organized in accordance with the following principles:

1. Development of the cognitive sphere of students;

2. Taking into account the peculiarities of the structure of lexical skills for operating with the terminological vocabulary of professional orientation;

3. The principle of the complexity of teaching the lexical aspect of speech in unity with the grammatical and phonetic elements of speech;

4. Phased formation of lexical actions.

The system of lexically directed teaching (linguistic, conditional speech) exercises and control tasks ensures the assimilation of lexical knowledge, the development of 
lexical skills for the conscious operation of terminological vocabulary in productive and receptive types of speech activity. Various forms of assessment were used to assess the level of formation of skills in operating with terminological vocabulary: current, periodic, final. The assessment of the correct understanding of the meanings of new terms by students was carried out by presenting the terminological vocabulary in several diverse contexts, providing for multiple receptions of the activated terms.

The results of experimental teaching using a system of lexically directed exercises indicate a significant expansion of students' stock of terminological vocabulary of the professional language of the electric power industry. Proper assessment, techniques, and exercises increase the level of formation of lexical skills. These skills help the educational process participants to successfully operate with this type of vocabulary.

The conducted research has shown a significant increase in productivity of the proposed methodology for teaching terminological vocabulary of the electric power industry's professional language. The success of the formation and improvement of lexical skills in operating with this type of vocabulary creates favorable prerequisites for the communication process in professionally significant situations. The goals and objectives set in the study have been achieved, namely: the features of the functioning of the lexical skills of operating with the terminological vocabulary of the professional language of the electric power industry have been determined; a typology of professional terms of the terminological vocabulary of the professional language of the electric power industry has been developed; a technology for teaching students the skills of using terminological vocabulary in the process of oral and written communication was developed based on this typology; a system of lexically directed exercises for mastering terminological vocabulary in different areas of the future specialist's activity has been developed. The newly acquired lexical skills of students, taking into account the lexical features of the terminological vocabulary of professional orientation, have been shown to be stable and less susceptible to the deautomation process. This level of development of lexical skills in operating with terminological vocabulary increases the quality of mastering new lexical material, which in turn has a positive effect on the quality of teaching a foreign language in a non-linguistic university as a whole. The methodological learning process must be built on the basis of the strategies and techniques described in the research, taking into account the gradual formation of lexical actions, which are practiced in the system of lexically directed exercises.

In the course of the experimental training of students in the terminological vocabulary of agricultural orientation, the consistency of the proposed methodology for teaching this type of vocabulary in a non-linguistic university was proved. This means that this technique can be used in the practice of teaching special (terminological) vocabulary in non-linguistic universities. The developed approach to the formation and improvement of the lexical skills of operating with terminological vocabulary, as well as the process of teaching it as a whole, seems to be quite constructive and can be applied with appropriate modification not only at the stage of higher professional education but also at the middle stage - in specialized classes of secondary school and at the stage of postgraduate education (postgraduate study).

The hypothesis put forward in the course of the research that the mastery of terminological vocabulary in their specialty by students of a non-linguistic university will be more effective provided that cognitive, informational and compensatory strategies for working on this type of vocabulary are used rationally based on specially developed methods, techniques and a system of lexically directed exercises, was proven in full. As a result of the conducted research, new areas of research of the problem of teaching terminological vocabulary in the specialty have opened, which need more detailed consideration, namely: further study of the context (single-purpose and multi-purpose) and the methods of teaching such a complex type of vocabulary;

XLinguae, Volume 14 Issue 1, January 2021, ISSN 1337-8384, eISSN 2453-711X 
clarification and differentiation of the concepts of the "terminological lexicon" and "special vocabulary"; detailed development of a methodology for teaching terminological vocabulary at other stages (except for university) of teaching a foreign language; functioning of terminological vocabulary in written speech. The prospect of this study lies in the fact that the described method of teaching the terminological vocabulary of a foreign language can be used in teaching students of other specialties, including non-linguistic specialties. The proposed organization of a terminological dictionary for educational purposes can help authors prepare professionally-oriented textbooks in a foreign language for other sub-languages in diverse sectors.

\section{Conclusion}

Much of what happens at university cannot be easily transferred to the online environment. Teaching methods, learning content, learning rates, interaction models, and assessment methods - all this may require adaptation when switching to training in online mode. Creative uses of new techniques and technologies can be beneficial for "non-mainstream" activities; however, there are few examples that work on a large scale, reaching all students. Online teaching is very different from face-to-face teaching, requiring a specific set of skills and new approaches. Even teachers with extensive experience in using educational technologies and progressive teaching techniques when teaching students in the classroom find it difficult to work exclusively in the online environment.

During the research, we came to the following conclusions: firstly, the content of the stage-by-stage professionally oriented training of students of non-linguistic universities has been developed, contributing to the formation of foreign-language communicative competence; also, the designed structural-content model of the formation of professional foreign language competence of students of non-linguistic universities in the process of vocational education can be used to optimize the professional training of technical specialists in the context of higher professional education. Developed and tested manuals and methodological developments have been introduced into the practice of vocationally oriented teaching of students of nonlinguistic universities, which contribute to the effective formation of foreign language communicative competence of students in the process of vocationally-oriented education. "Methodological guide for teaching terminological vocabulary of the professional language of the electric power industry," "Methodological manual for the formation of students' terminological vocabulary of the professional language of the electric power industry," and a new set of criteria for the formation of foreign language communicative competence of students of non-linguistic universities developed in the course of the study. These materials help assess the structure of newly-acquired competencies and allow monitoring the quality of professionallyoriented teaching of a foreign language in higher professional education conditions. The proposed critical diagnostic apparatus of research can be widely used to form a foreign language communicative competence of students of non-linguistic universities in the course of vocationally oriented teaching of a foreign language. The reliability and validity of the research results obtained ensured by the initial methodological positions and the theoretical basis of the research; application of methods corresponding to the subject, goal, and objectives of the study; monitoring the results at all stages of the process of forming the foreign language communicative competence of students of non-linguistic universities. Conclusions are made based on qualitative and quantitative analyses of the data obtained and a fitting approbation of research results in teaching practice. The authors' model of the formation of foreign language communicative competence of students of non-linguistic universities in the process of professionally oriented education was tested in the course of experimental work. 
Online learning is impossible without an IT infrastructure, which requires significant investments, including an online learning platform, as well as high-quality online courses that provide effective training and support for learners in an online environment. In the current situation, when the transition to online learning is carried out as quickly as possible, all these conditions must be created in advance, and teachers must have experience in using online learning tools and student support services.

\section{Bibliographic references}

ALIFERENKO, L. B. 1982. Structural and semantic properties of synonymous terminology, Structural and semantic features of industry terminology: Interuniversity. Sat. scientific. tr. / Voronezh Technological Institute. Voronezh, p. 117-123.

ALL, A. A. 1979. Methods of teaching reading literature in the specialty in German: (non-linguistic university): Author. dis. Cand. ped. Sciences, $18 \mathrm{p}$.

ALKHAZASHVILI, A. A. 1988. The basics of mastery of oral foreign language speech. In: Education, 128 p.

ALYAKRINSKY, V. S. 1971. About talent and abilities. In: Knowledge, 174 p.

ANTONOVA, M. V. - LEICHIK, V. M. 1990. Functions of a scientific and technical term and their application in information processes // NTI, vol. 11, n. 2, pp. 15-23.

ANTYSHEV, A. N. 1980. Terminology in special scientific texts, Questions of analysis of a special text: Interuniversity. topics. scientific. Sat. Ufa, pp. 7-9.

ANYUSHKIN, E. S. 1984. Substantive terms and their extralinguistic determinism in the German terminology of sugary substances: Author's abstract. dis. ... Cand. philol. Sciences, Kiev, 24 p.

ATABAEVA, F. K. 2004 Methodology for the use of innovative communication technologies in foreign language education of students of non-linguistic universities: abstract. Almaty, 22 p.

BIBOLETOVA, M. Z. 2005. Sample programs of secondary general education. Foreign languages / M.Z. Biboletova, N.P. Gracheva, E.N. Sokolova, N.N. Trubaneva. In: Education,

BIM, I. L. 2007. Competence approach to education and teaching foreign languages / I.L. Beam, A.V. Khutorskoy // Competence in education: design experience: collection of articles. scientific. tr. / ed. A.V. Khutorsky. In: Research and Development Enterprise "INEC", 327 p.

DEVYATOVA, 2017. Modern philology: materials of the V International. scientific. conf. In: Samara: ASGARD, pp. 53-55.

CHAKLIKOVA, A. T. 2011. Categories "competence" and "competence" in the modern educational paradigm, In: Bulletin of KazNU. Series of pedagogical sciences. n. 2, pp. 9-17.

COMMON EUROPEAN FRAMEWORK OF REFERENCE FOR LANGUAGES, 1996. Learning, Teaching, Assessment. Strasbourg: Language Policy Unit,

DE MARTINO M. - GUSHCHINA Y.S - BOYKO Z.V. - MAGNANINI A. SANDOR I. - GUERRERO PEREZ B.A. - ISIDORI E. 2020. Self-Organisation in Lifelong Learning: Theory, Practice and Implementation Experience Involving Social Networks and a Remote Format. RUDN Journal of Psychology and Pedagogics. vol. 17. N. 3. pp.373-389. ISSN 2313-1705. doi: 10.22363/2313-1683-2020-17-3-373-389 GADUSOVA, Z. - HASKOVA, A. - PREDANOCYOVA, L. 2019. Teachers' professional competence and their evaluation. In: Education and Self Development, vol. 14, n. 3, pp. 17-24. ISSN 1991-7740.

GAVRILENKO, N.N. - BIRYUKOVA, YU.N. 2019. Forecasting the translation profession development: Foresight Technology. Journal of history culture and art research. vol. 8, n. 4, pp. 123-134. doi: 10.7596/taksad.v8i4.2365

XLinguae, Volume 14 Issue 1, January 2021, ISSN 1337-8384, eISSN 2453-711X 
GOLOVIN, B.I. 1996. Actual problems of stylology and terminology: Theses of the interstate. ISU im. Lobachevsky, N. Novgorod, $100 \mathrm{p}$.

GUZHELYA, D. - KURILENKO, V. - BIRYUKOVA, YU. 2020. The specifics of distance methodological support for foreign language teachers in a foreign language environment. Revista Inclusiones, vol 7. pp. 22-31, Available online: http://revistainclusiones.org/index.php/inclu/article/view/1312

KOBYLAREK, A. 2010. Integration of elderly citizens through learning. New educational review, vol. 22, n. 3, n. 4, 24 p. ISSN 1732-6729

KUNANBAEVA, S. S. 2005. Modern foreign language education: methodology and theory. In: Almaty, Edelweiss, 264 p.

KUZNETSOVA, S. A. - LEONTIEV, A. A. 1998. Psychological and pedagogical foundations of updating the methods of teaching foreign languages: Lecture-report. A.A. Leontiev. In: Research Center for the Problems of the Quality of Training of Specialists, $24 \mathrm{p}$.

MIRZA N.V. Professional competence of a teacher. 254 p.

NAZARBAYEV, N. A. 2020. New Kazakhstan in a new world // Kazakhstanskaya Pravda. n. 33 (25278).

NAZARBAYEV, N. A. 2020. The plan of the nation - 100 concrete steps to implement five institutional reforms of the Head of State Nursultan NAZARBAYEV, N. A.

SAGADIEVA K.K. - MIRZA N.V. 2015. Foreign language communicative competence as an integral part of the successful professional activity of a specialist. Collection of materials of the International Scientific and Practical Conference "Dnyvedy 2015". In: Prague: Educationandscience, pp. 32-36.

SCHELENBERG, W. 1994. Untersuchungen zur Strategic der Sprachgestaltung ausgewahlter Fachtextsorten aus Gegenwart und Neuzeit, Hamburger Arbeiten zur Fachsprachenforschung. Bd. 2. -Tostedt,

SHCHUKIN, A. N. 2004. Teaching foreign languages: theory and practice: a textbook for teachers and students. A.N. Shchukin. In: Filomatis, 416 p.

SKINNER, B. F. 1980. Beyound Freedom and Dignity. New York: Bantam Books, In: Vintage books, $215 \mathrm{p}$.

SKINNER, B. F. 1980. Beyound Freedom and Dignity. New York: Bantam Books, In: Vintage books, $215 \mathrm{p}$.

SOLOVOVA, E. N. 2003. Methodology for teaching a foreign language: Basic course of lectures: A guide for students ped. universities and teachers / E.N. Solovov. - 2nd ed. In: Education, 239 p.

SURYGIN, A .I. 2000. Fundamentals of the theory of learning in a language foreign to students. / A.I. Surygin. - St. Petersburg: Zlatoust Publishing House, 230 p. 5

SAFONOVA, V. V. 1996. Studying the languages of international communication in the context of the dialogue of cultures and civilizations. In: Voronezh: Istoki, $239 \mathrm{p}$.

TERMINOLOGY WORK IN SUBJECTFIELDS. 1993. Proceedings 3rd Infoterm Symposium. Wien,

TROYANSKAYA, S. L.2016. Fundamentals of the competence-based approach in higher education: textbook. / S.L. Trojan. Izhevsk: Publishing Center "Udmurt University", $176 \mathrm{p}$.

TSATUROVA, I. A. 2004. Testing of oral communication: Study guide / I.A. Tsaturova, S.R. Baluyan. In: Higher. shk., n. 127, pp. 51-52

UTEUBAEVA, E. A. 2001. Methodological recommendations for the IWS and IWS in the discipline "Language for Academic Purposes". In: Almaty, Evero, 68 p.

VAN EK, A. - TRIM, J.L. 2002. Vantage. Cambridge University Press, 176 p.

WIISTER, E. 1970. Internationale Sprachnormung in der Technik, besonders in der Elektrotechnik/ Sprachforum, Beiheft 2. Bonn, 
ZATKOVA, T. - AMBROZY, M. 2019. VET teacher preparation in Slovakia and the new professionals-Entrepreneurship trainers for VET, In: TEM Journal, vol. 8, n. 1, pp. 248-254. ISSN 2217-8309.

ZHETPISBAEVA, B. A. - SHAIKHYZADA, ZH.G. - KOSTINA, E.A. 2015. Components of a foreign language professional-communicative competence of students of non-language specialties. Available online: http://articlekz.com/article/11919

Words: 5531

Characters: 38333 (21,30 standard pages)

Kurmanbayeva Tolganay

Kazakh National Pedagogical University Abai

Dostyk avenue 1

500050 Almaty

Kazakhstan

Almaty University of Energy and Communications named after G. Daukeev

Baitursynov street 126/1

500050 Almaty

Kazakhstan

Prof. Shaibakova Damina

Dostyk avenue 1

Baitursynov street 126/1

500050 Almaty

Kazakhstan

Doc. Tuleup Meirimkul

Almaty University of Power Engineering and Telecommunications (AUPET) named after G. Daukeev

Baitursynov street 126/1

500050 Almaty

Kazakhstan

Assoc. prof. Nurmakhanova Marzhan

Doc. Kubdasheva Karlygash

Almaty University of Energy and Communications named after G. Daukeev

500050 Almaty

Kazakhstan

nurzhazhan@mail.ru

XLinguae, Volume 14 Issue 1, January 2021, ISSN 1337-8384, eISSN 2453-711X 